\title{
Bring Entrepreneurship into Supply Chain Partner Networks: The Influence on Best-value Supply Chains
}

\author{
Xun Li \\ Nicholls State University \\ Clyde W. Holsapple \\ University of Kentucky
}

A firm's design for its supply chain partner network reveals the firm's pursuit of resources and opportunities to build up the best-value supply chains in terms of agility, adaptability and alignment. This study develops a research framework, proposing that a firm with an entrepreneurial supply chain partner network, characterized with strong and highly-diversified ties, enjoys a high level of relational learning, trust and integration, and contending that the three types of relational competencies exert positive influence on supply chain agility, adaptability, and alignment. The framework offers a theoretical platform to guide future research and practice concerned with supply chain entrepreneurship.

\section{INTRODUCTION}

In today's global economy, competition is increasingly being fought at the supply chain level: rather than competing "firm versus firm", organizations are battling "supply chain versus supply chain" (e.g. Davis and Spekman, 2004; Lambert and Cooper, 2000). In seizing opportunities and handling disturbances/risks that the increasingly turbulent business environment presents, best-value supply chains characterized by agility, adaptability, and alignment, have been highlighted as a crucial means for firms to obtain sustainable competitive advantage and superior firm performance (e.g. Ketchen and Hult, 2007; Lee, 2004; Li et al., 2015).

Within this context, scholars have been called to investigate the impact of work design on best-value supply chains (e.g., Li et al., 2008, 2009). Two major issues motivate this call for placing the study of work design high on the research agenda. First, the design of work has been and will continue to be a central problem challenging organization theory and practice, because the system of arrangements and procedures for doing work affects us every day (Sinha and Van de Van, 2005). Second, the practice of work in a supply chain had been changing dramatically over the past 20 years and these changes are outpacing our theories and methods for representing and explaining them (Child, 2005).

The biggest change in work practice is that work activities, undertaken to develop, produce and deliver a product, have become globally distributed in supply chain networks, transcending the boundaries of organizations and countries (Borgatti and Li, 2009). As a result, the design of supply chain partner network has become the focus of a firm's work design. The value of effective design of supply chain partner networks is reflected in how firms such as Walmart, Toyota and Dell have developed their 
supply chain partner networks as strategic weapons to gain advantages over peers. General Electric has increased revenues by $60 \%$ and doubled profits by putting customers into its work network for innovation (Magee, 2009).

Work networks do not emerge at random, nor are they ecologically niches waiting to be filled (Burt, 1992). Firms can purposely design their networks to have access to new market opportunities, best managerial practices, work support, and so on (Zaheer and Zaheer, 1997). In this line, we contend that the design of supply chain partner network reflects a firm's strategic choices of supply chain partners in pursuit of entrepreneurship: leveraging connections and ties in supply chain partner network in discovering and exploiting opportunities to obtain competitive advantages and create value. However, to date, few studies have investigated how a firm injects entrepreneurial factors into its design of supply chain partner networks, and how the resulting network patterns affect the development of best-value supply chains.

In this study, we apply social network and entrepreneurship theories to supply chain partner network design to derive how the entrepreneurial supply chain partner network facilitates the forming of three types of relational competencies (i.e., relational learning, relational trust, and relational integration). We contend that the three types of relational competencies contribute to the building of best-value supply chain on agility, adaptability, and alignment. The rest of this article is organized as follows. In the section of theoretical foundations, we provide a brief review of best-value supply chains, introduce a typology of supply chain partner network to identify the relational dimensions of an entrepreneurial supply chain partner network, and describe the three types of relational competencies. Next, we present a research framework and offer propositions to explain the mechanisms through which the entrepreneurial supply chain partner network affects relational competencies, and relational competencies exert positive impact on the development of best-value supply chains. The article ends with a discussion of theoretical and managerial implications, and future research directions.

\section{THEORETICAL FOUNDATIONS}

\section{Best-value Supply Chains}

To create and sustain competitive advantages in today's turbulent global environment, firms must build their supply chains on agility, adaptability, and alignment (Ketchen and Hult, 2007; Lee, 2004; Li et al., 2015). Agility refers to the capability of a supply chain to be alert and respond to sudden changes in demand or supply (Lee, 2004; Li et al., 2008). Adaptability refers to the capability to track macroeconomic changes (e.g., structural shifts in markets), and adjust supply chain designs to respond to those changes (Lee, 2004). Alignment refers to the capability for creating shared incentives among participants for better performance (Lee, 2004).

To distinguish from traditional supply chains, Ketchen and Hult (2007) refer to supply chains with superior agility, adaptability, and alignment as best-value supply chains. Compared to traditional supply chains, best-value supply chains create value for firms by focusing on strategic supply chain management (SCM) - the use of a supply chain as a means to excel along multiple competitive priorities that drive firms' competitive performance (Ketchen and Hult, 2007; Hult et al., 2004).

\section{Work Design for a Supply Chain: Supply Chain Partner Network Design}

In an increasingly global economy, work practice in a supply chain has become geographically dispersed. Supply chain work often develops in a network of supply chain partners cutting across locations, the boundaries of firms, industries and nations. For example, Sinha and Van de Ven (2005) claim that modern organizations reconfigure the arrangements of doing work by focusing on their distinctive competence, outsourcing the rest and playing the niche role as nodes in work networks. Therefore, we need to take a network perspective to view today's work design for a supply chain.

We take the position that a firm's work design should anchor on its supply chain partner network for two major reasons. First, in today's global economy, work design for a supply chain is a function of supply chain partner selection involving public and private parties within and across industry boundaries. 
Second, it has been recognized in a growing body of research that buyer-supplier relationships/partnerships are critical strategic options for supply chain capability related issues, such as new product development (e.g, Petersen et al., 2005), risk mitigation (e.g., Braunscheidel and Suresch, 2009), and so on. This leads us to introduce this concept of work network: supply chain partner network. Doing so is consistent with the common practice in social network research, which focuses on specific types of networks, such as "friendship network" or "advice network" (Brass 1995; Krackhardt 1990).

To understand the impact of a supply chain partner network, we must first discuss the patterns of partnership networks that a firm can develop. This discussion centers around a network typology adapted from the work of Higgins and Kram (2001). Although their typology was developed to understand mentoring in a current-career context, we argue that it also applies to supply chain partner network.

\section{Network Dimensions}

The network typology is characterized by two network dimensions: relationship strength and network diversity. Relationship strength refers to the duration and frequency of communication among network participants. Network diversity refers to the range of social systems from which the focal firm (i.e., an ego node in social networks) draws and receives support for work. The two dimensions are also consistent with core concepts in social network theory and research (for reviews, see Brass, 1995 and Ibarra, 1993)

\section{Relationship Strength}

In general, relationships or ties may be characterized as weak (i.e. infrequent communication), strong (i.e., frequent communication), or indeterminate (as with casual contacts or strangers). For the purpose of characterizing a supply chain partner network, we consider relationship strength as a continuum that ranges from weak ties to strong ties. Social network researchers have examined the role of weak ties versus strong ties in the acquisition of novel information. The power of weak ties derives from the likelihood that they may be exposed to different information than actors with whom the focal actor interacts intensively (Granovetter, 1973). More recently, however, attention has shifted to the role of strong ties. Research from a variety of disciplines has shown that strong ties transfer tacit and complex knowledge. Network actors bonded by strong ties tend to be highly motivated to collaborate with each other (Borgatti and Cross, 2003; Hansen, 1999; Higgins and Kram, 2001; Krackhardt, 1992).

\section{Relationship Diversity}

In social network research, the concept of diversity concerns the extent to which the information provided by different participants in one's network is not similar or redundant (Burt, 1983, 1992; Granovetter, 1973). The less redundant the information provided by an ego node's network, the greater its access to valuable resources and information. There are two basic ways to define diversity: 1) range, the number of different social systems from which relationships stem, and 2) density, the extent to which network nodes are connected to one another (Brass, 1995; Burt, 1983; Krackhardt, 1994).

Consider the following example to illuminate the premises of network range and network density. Suppose there is a focal firm in consumer goods industry whose supply chain network spans industry boundaries involving an aircraft manufacturer, a personal computer manufacturer, and an automobile manufacturer. This firm's network range is relatively high. In contrast, a firm's partner network with all ties from within the same industry has less range. Consider a focal firm that is a manufacturer and has ties to three different parties (i.e., alter nodes in social network), for example, a key supplier, a distributor, and a primary customer. If the four nodes are connected pair-wise with each other, then the firm's partner network density is high. On the other hand, if there are no direct ties among the four alter nodes, the network density is low. Here, we adopt range as our specific conceptualization for network diversity. This is because it more closely captures the real-world environment for a firm's supply chains: the four nodes in the manufacturer's partner network normally do not have working relationships with each other. Therefore, we define diversity of supply chain partner network in terms of range: the number of different social systems from which the information ties originate. 


\section{Patterns of Supply Chain Partner Network}

As illustrated in Figure 1, the two network dimensions yield four distinct network patterns: (1) Receptive network (low network diversity and weak relationship); (2) Traditional network (low network diversity and strong relationship); (3) Opportunistic network (high network diversity and weak relationship); (4) Entrepreneurial work network (high network diversity and strong relationship). In Figure 1, supply chain partners are identified with S1, S2, S3, and S4 and the focal firm with F. Consistent with social network research, we depict the connections between the focal firm and its supply chain partners with lines: solid lines for strong relationships and dotted lines for weak relationships (Burt, 1983). We use ovals to denote the boundaries of social systems.

\section{FIGURE 1 SUPPLY CHAIN PARTNER NETOWRK TYPOLOGY}

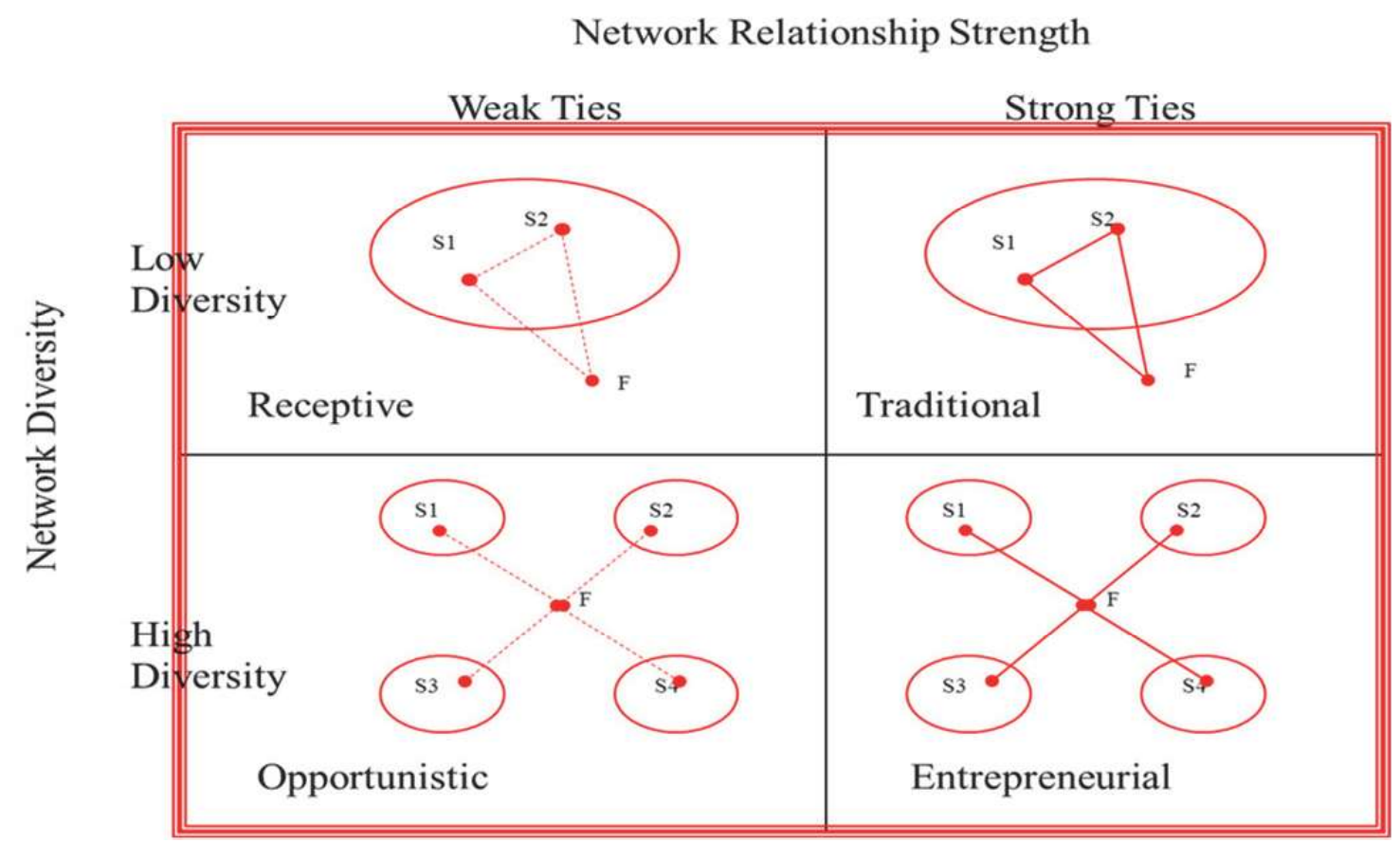

(Adapted from Higgins and Kram, 2001)

\section{Receptive Network}

The distinguishing feature of a receptive network is the ego actor's openness to receiving work assistance from the same social system but does not actively initiating or cultivating work relationships.

\section{Traditional Network}

Traditional networks exhibit a clique-like structure composed of interconnected strong ties (Burt, 1980). We use the term traditional, because these work ties come from the same social system (e.g. S1, S2 work for the same firm), which is generally assumed to be the classic case of work. Given that the work supporters are affiliated with the same social system, it is likely that there will he interconnection between them. As in the receptive work network, the ego actor is more likely to receive similar information, yet unlike the receptive work network, the work support provided is less likely to be strong. 


\section{Opportunistic Network}

The distinguishing feature of opportunistic network is that an ego actor's openness toward receiving work support from multiple sources and its passive stance toward actively initiating and cultivating such relationships.

\section{Entrepreneurial Network}

The key distinguishing feature of an entrepreneurial network is that it is made up of heterogeneous work supporters who are highly motivated to act on behalf of the ego actor and who collectively provide the ego with access to a wide array of work related information. In the past, social network researchers have pointed out that strong ties will lead to network density because people with whom an individual has strong ties will tend to be affiliated (Berscheid and Walster 1978: Byne, 1971). Such cases are always found within bonded social systems, such as organizations. However, for a supply chain partner network with work supporting ties spanning organizational boundaries and emerging from different social systems, strong ties do not necessarily imply interconnection among them.

\section{Relational Competencies}

In the modern competitive environment, the ultimate success of a firm depends on its management's ability to leverage the relational competencies of the firm's business relationships in its supply chains (Christopher, 1997; Drucker, 1998; Lambert, 2008). Particularly, the importance of three relational competencies has been highlighted in prior research: learning, trust and integration. The learning dimension highlights the importance of shared representation, understanding and systems of meaning for work practices/activities (e.g., Dyer and Hatch, 2006; Modi and Mabert, 2007). The trust dimension address motives, expectations and norms among related parties (Carey et al., 2011; Cousins et al., 2006; Day et al., 2013; Krause et al., 2007; Lawson et al., 2008). The relational integration refers to the seamless coordination among supply chain partners (Cousins and Menguc, 2006; Fabbe-Costes and Jahre, 2007; Petersen et al. 2005).

There has been a growing trend for firms to create external linkages based on the sharing of information (Borgatti and Cross, 2003). This is the realm of relational learning, which can be viewed as a knowledge transmission process among supply chain partners, refers to the flow of implicit and explicit information (Modi and Mabert, 2007). Effective learning between firms can be characterized as genuine, frequent and involving personal contacts (Dyer and Hatch, 2006). However, opportunistic behavior is a common reason why firms fail to achieve high performance. Here, trust comes into play. Relational trust develops in the process by which individuals and organizations come together, interact and form psychological connections for mutual gain or benefit (Coleman, 1988). Trust entails the active participation by the actors involved toward sustaining the relationship (Dyer and Singh, 1998).

Typically, the goal of managing relationships in a supply chain is to integrate supply chain processes (Flynn et al., 2010; Frohlich and Westbrook, 2001). This is the focus of relational integration, which supplements the psychological level of relational trust by a level that is focused on the coordination of work systems (e.g., enterprise resource planning) and processes (e.g., inventory management) among supply chain partners.

\section{RESEARCH FRAMEWORK AND PROPOSITIONS}

A firm's work network for its supply chain serves the evolving needs of a set of customers and thus must utilize the supply chain partners' relational competencies to stay agile, adaptable, and aligned in addressing changes in customer needs. As presented by the research framework in Figure 2, we advance the propositions that a firm can develop its supply chain partner network in the manner that the relationship strength and network diversity are leveraged in the forming of relational learning, trust, and integration. 


\section{FIGURE 2}

\section{LINKING SUPPLY CHAIN PARTNER NETWORK DESIGN TO BEST-VALUE SUPPLY CHAINS}

\begin{tabular}{|c|c|c|}
\hline $\begin{array}{l}\text { Supply Chain Partner } \\
\text { Network Design }\end{array}$ & Relational Competencies & $\begin{array}{l}\text { Best-value } \\
\text { Supply Chains }\end{array}$ \\
\hline $\begin{array}{l}\text { Network Dimensions } \\
\text { - } \quad \text { Tie diversity } \\
\text { - } \quad \text { Tie strength }\end{array}$ & $\begin{array}{ll}\text { - } & \text { Relational Learning } \\
\text { - } & \text { Relational Trust } \\
\text { - } & \text { Relational Integration }\end{array}$ & $\begin{array}{l}\text { - Agility } \\
\text { - Adaptability } \\
\text { - Alignment }\end{array}$ \\
\hline
\end{tabular}

\section{Supply Chain Partner Network Design and Relational Competencies}

The selecting of supply chain partners and then managing these choice relationships are the primary source of relational capital (Cousins et al., 2006). Taking a social network perspective, we contend that the pattern of a firm's supply chain partner network can conform to one of the four network patterns (i.e., receptive, traditional, opportunistic, and entrepreneurial). As shown in Table 1, different network pattern has distinct impacts on relational learning, trust and integration.

TABLE 1

NETWORK PATTERNS AND RELATIONLA COMPETEMCIES

\begin{tabular}{|r|c|c|c|}
\hline $\begin{array}{r}\text { Receptive work } \\
\text { network (low } \\
\text { network diversity, } \\
\text { weak relationship) }\end{array}$ & $\begin{array}{c}\text { Redundant information } \\
\text { sharing; low level in both } \\
\text { public and private } \\
\text { knowledge }\end{array}$ & $\begin{array}{c}\text { Low level of } \\
\text { trust } \\
\text { trust }\end{array}$ & $\begin{array}{c}\text { Low level of } \\
\text { integration }\end{array}$ \\
\hline $\begin{array}{r}\text { Traditional work } \\
\text { network (low } \\
\text { network diversity, } \\
\text { strong relationship) }\end{array}$ & $\begin{array}{c}\text { Redundant information } \\
\text { sharing; high level in } \\
\text { public knowledge but low } \\
\text { level in private knowledge }\end{array}$ & $\begin{array}{c}\text { High level of } \\
\text { trust }\end{array}$ & $\begin{array}{c}\text { High level of } \\
\text { integration in a closed } \\
\text { work network }\end{array}$ \\
\hline $\begin{array}{r}\text { Opportunistic work } \\
\text { network (high }\end{array}$ & $\begin{array}{c}\text { Non-redundant } \\
\text { information sharing; high } \\
\text { level in public knowledge } \\
\text { but low level in private } \\
\text { knowledge }\end{array}$ & $\begin{array}{c}\text { Low level of } \\
\text { trust }\end{array}$ & $\begin{array}{c}\text { Low level of } \\
\text { integration }\end{array}$ \\
$\begin{array}{r}\text { weak relationship) } \\
\text { Entrepreneurial }\end{array}$ & $\begin{array}{c}\text { Non-redundant } \\
\text { information sharing; high } \\
\text { work network (high } \\
\text { network diversity, } \\
\text { level in public and private } \\
\text { strong relationship) }\end{array}$ & $\begin{array}{c}\text { High level of } \\
\text { trust }\end{array}$ & $\begin{array}{c}\text { High level of } \\
\text { integration in an open } \\
\text { work network }\end{array}$ \\
\hline
\end{tabular}

The firm with either receptive or traditional network pattern tends to have a low level of learning. On the other hand, the firm with either opportunistic or entrepreneurial work-network has a high level of learning. Compared to the firm with receptive or opportunistic network pattern, the firm with traditional or entrepreneurial work-network pattern is more likely to have high level of relational trust and integration. Therefore, we further contend that, to develop relational competencies in its supply chain partner network, a focal firm should design the network according to the pattern of an entrepreneurial network. 
When a focal firm selects supply chain partners solely on transaction-by-transaction basis, the relationships formed in the focal firm's supply chain partner network are arm's length ties. Arm's length ties are weak ties, because such ties are cool and atomistic, and actors are motivated by incremental profit seeking (Uzzi, 1997). Consider, for example, a manufacturer that only uses a supplier for one transaction because that supplier provides the lowest price. The network pattern derived from such a supply chain partner network is a receptive one. The information transferred is either public knowledge or generic inventory information. Public knowledge is reported through standard instruments such as company reports, audited financial statements, regulatory filings, advertised bid and ask prices, price quotes, contractual stipulations, warranties, and other forms of prepared information accessible in the public domain (Uzzi and Lancaster, 2003). Generic, point-of-sale data or inventory status information exchanged in supply chain partner networks are tied to operational processes and provide little insight for strategic redirection. Arm's length ties may promote exploitative learning through the collection and reporting of standard information that enables firms to enhance their current competencies and processes. However, such ties do not afford firms the capability to detect opportunities for innovation through restructuring their competencies and processes (Uzzi and Lancaster, 2003). Additionally, although the focal firm can easily replace arm's level ties, it is hard to build up trust and integration through weak ties.

A focal firm can easily establish strong ties with its supply chain partners if that firm uses the following criteria to select partners: open and honest communication, and commitment to a long-term relationship, and reciprocity. Supply chain partners with those traits, showing the ability to understand and rationalize the focal firm's intent, are important toward maintaining a strong buyer-supplier relationship (Wu and Choi, 2005). The network pattern derived from a supply chain partner network composed of strong ties is a traditional one.

Malhotra et al. (2005) propose that strong ties between collaborative supply chain partners facilitate privileged, private information sharing between partners, hence enhancing opportunity detection. Privileged information can be related to a firm's strategy, distinctive competencies, undocumented product capabilities, critical customer or supplier dependencies, and so forth (Uzzi and Lancaster, 2003). In addition, privileged information is specific to the receiving partners in terms of being proprietary and confidential. It provides the partner a unique perspective not available otherwise. An example of the privileged information exchanges used in the research by Malhotra et al. (2005) is an optical electronics manufacturer's effort to inform the channel about the timeframe in which a new product is going to be introduced and the associated transaction plan. The close collaborators (i.e., supply chain partners with strong ties) are given this information six months in advance, while the rest of the supply chain players are only given a month's notice.

Once supply chain participants are engaged in a partner network, how much they can contribute to relational competencies is affected by the participants' own network patterns. If a supplier has connections to other parties outside the boundary of the supply chain partner network (e.g., range from firms in the same industry but not in the same supply chain network, to firms in other industries), we say this supplier has relatively high network diversity. Compared to supply chain partners with lower network diversity, supply chain partners with high network diversity function as boundary spanners, which are more alert to divergent ideas sparked by their boundary-spanning ties (Kim et al., 2006) and interpret environmental conditions and replaying that information to organization decision better (Huber, 1991). Strong boundary-spanning ties facilitate the transfer of privileged information from a wide range of sources, thereby enhancing learning greatly. Wu and Choi (2005) concluded in their case studies that a supplier with high network diversity is more likely to become a solution provider and, consequently, attains a larger share of supply responsibility from the buyer, thus contributing to supply chain integration. Zhang et al. (2011) found that boundary spanning capabilities are positively associated with trust development in buyer-supplier relationship.

When a firm selects its supply chain partners based on open and honest communication, commitment to a long-term relationship, reciprocity, and network diversity, we say that this firm can design an entrepreneurial supply chain partner network. As illustrated above, an entrepreneurial supply chain partner network, characterized with strong supply chain partnership and high network diversity, 
contributes to the forming of all three types of relational competencies. Thus, we advance the following propositions:

Proposition 1a: A firm with an entrepreneurial design of supply chain partner network enjoys a higher level of relational learning than firms with other design patterns.

Proposition 1b: A firm with an entrepreneurial design of supply chain partner network enjoys a higher level of relational trust than firms with other patterns.

Proposition 1c: A firm with an entrepreneurial design supply chain partner network enjoys a higher level of relational integration than firms with other patterns.

\section{Relational Competencies and Best-value Supply Chains}

The extent to which the three capabilities of best-value supply chains (i.e., agility, adaptability and alignment) can be enhanced is determined by the level of relational competencies cultivated in a firm's supply chain partner network.

\section{Relational Learning and Best-value Supply Chains}

An important way to enhance agility, adaptability and alignment is relational learning (Ketchen and Hult, 2007). Kang et al. (2007) suggest that relational learning provide two types of cognitive mechanisms that can facilitate learning outcomes: common architecture knowledge and common component knowledge.

Common architecture knowledge refers to a shared understanding among network participants about the interconnection of all components in some domain of interest, or of how things fit together (Matusik and Hill, 1998). To be agile and adaptable, a supply chain needs to be alert to unexpected changes (Li et al., 2009, 2017). The capacity of alertness benefits from the availability of knowledge that is sufficient in diversity and detail. Because of the cognitive limitation of any given individual, knowledge availability is greatly enhanced by knowledge shared and transferred among participants. In this sense, common architecture knowledge provides a cognitive mechanism to transfer and understand large amount of knowledge and complicated knowledge and experiences difficult to conceptualize adequately (Hill and Levenhagen, 1995).

A supply chain involves the coordinated effort and integration of various parties. To be agile and adaptable, a supply chain also needs to be well-coordinated and integrated so that it can take quick responsive actions to address changes. In that sense, common architecture knowledge is needed. Common component knowledge refers to the knowledge of "parts" or "components". Specifically, it is overlapping knowledge that relates to a subroutine or discrete aspect of a firm's operations. To explore new opportunities or alternative ways of work, supply chain partners must know enough about the content domain of other members' expertise to assimilate it, interpret it, and recognize its value in work practices. Common component knowledge allows supply chain partners to recognize, understand and assimilate novel knowledge from a wide range of related participants and enables partners to be aligned with each other in taking agile and adapting actions in response to new opportunities. In line of the above discussion, we have the following propositions:

Proposition 2a: Relational learning exerts positive influence on supply chain agility.

Proposition 2b: Relational learning exerts positive influence on supply chain adaptability.

Proposition 2c: Relational learning exerts positive influence on supply chain alignment.

\section{Relational Trust and Best-value Supply Chains}

Work networks vary widely in the degrees to which members share a common goal or recognize a common authority (Sinha and Van de Ven, 2005). Participants in supply chains tend to pursue their different partisan interests in collaborating in the construction of an infrastructure that sustains the supply chain. As a result, incentives must be organized in such a way that all parties' interests are aligned. When work partners are simultaneously dependent on and vulnerable to the actions and decisions of others and when hierarchical authority does not exist, trust becomes a major organizing principle in a work system (McFvily et al., 2003). 
Researchers have argued that trust can take several distinct forms (Kang et al., 2007). Among them, institution trust can he developed through the security of rules, structures and organizations to buttress risks, and relational trust can be developed through direct positive exchange experience. Although both can deliver many advantages to the work system's agility, adaptability and alignment, we contend that relational trust among supply chain partners requires less effort than the institution trust to build and allows actors to customize to each other's needs flexibly. There is significant evidence to suggest that relational trust can lead to agility, adaptability and alignment related benefits, including improved delivery, early insights into new technologies, on-time product launches, buyer-supplier congruence, and others (Handfield et al., 1999; Lier and Choi, 2004; Monczka et al., 1998). Thus, we advance the following propositions:

Proposition 3a: Relational trust exerts positive influence on supply chain agility.

Proposition 3b: Relational trust exerts positive influence on supply chain adaptability.

Proposition 3c: Relational trust exerts positive influence on supply chain alignment.

\section{Relational Integration and Best-value Supply Chains}

Relational integration, as manifested in integrated and coordinated supply chain activities, is necessary for a firm to reconfigure supply chain resources and respond quickly to the changing environment. Successful SCM involves the coordination of activities between members of the supply chain (Croxton et al., 2001). Therefore, as an important element of relational integration, coordinated value activities within a firm enable the firm to make prompt strategic and operational decisions, adjustments and resource reconfigurations in response to unforeseen environmental disturbances and market changes. The existing literature has acknowledged that an important means for being agile and adaptable to changes is to integrate with its suppliers so that suppliers can be more responsive to the demands of the marketplace (Cousins and Menguc, 2006; Fabbe-Costes and Jahre, 2007; Petersen et al. 2005), thus enhancing supply chain agility and adaptability.

Nowadays, economic globalization has forced companies to adopt a more integrative perspective on supply chain alignment (Meijboom and Obel, 2007). Supply chain decisions are tightly interlinked and interrelated at all the decision-making levels. The literature on risk management generally concurs that relational integration plays a fundamental role to mitigate uncertainty with the help of synchronizing work flows in the supply chain system (Holweg and Pil, 2008; Ivanov, 2010). Relational integration creates value for a firm by aligning all relevant parties into the value creation process. On the other hand, when supply chain partners are misaligned, a series of adverse outcomes could occur. For instance, work flow may be interrupted; targets may be compromised or unattained; measures may neither be fully understood nor implemented; key initiatives may not be prioritized, optimized, or adequately funded (Paladino, 2000). In line with this reasoning, we propose that:

Proposition 4a: Relational integration exerts positive influence on supply chain agility.

Proposition 4b: Relational integration exerts positive influence on supply chain adaptability.

Proposition 4c: Relational integration exerts positive influence on supply chain alignment.

\section{CONCLUSION}

This study is the first to link the design of a firm's supply chain partner network to the development of best-value supply chains. The pattern of a supply chain partner network is conceptualized in terms of two dimensions: relationship strength and network diversity. Higgins and Kram (2001) describe the relationship network characterized with strong and diversified ties as an entrepreneurial network, which benefits firms most in terms of opportunity identification and exploitation. However, there is an apparent shortage in the SCM area regarding the value of an entrepreneurial design of a firm's supply chain partner network. In this study, we integrate the social network theories, entrepreneurship and SCM literatures to address the interplay among a firm's design of supply chain partner network, relational competencies, and attributes of best-value supply chains. 
This research speaks to supply chain managers. It suggests to them that the entrepreneurial design of supply chain partner network can help them to form and leverage such relational competencies as learning, trust, and integration. Specifically, it underscores the need for firms to think about how to inject entrepreneurship-related network dimensions into their designs for supply chain partner networks. It highlights the role of relationship strength and network diversity in developing relational competencies. The three types of relational competencies (learning, trust, and integration) conform to the three dimensions of relational capital (cognitive, affect, and structural) (Kang et al., 2007), which are critical resources in building supply chains on agility, adaptability, and alignment.

\section{Future Research}

This research extends the precepts of entrepreneurship to supply chain settings. Figure 3 displays the general framework used by researchers to address why, when, and how some individuals become entrepreneurs. This general framework is based on the combination of the Austrian School of economics (Kirznar, 1973, 1979) and cognitive psychology (e.g., Koppl, 2002). We can illustrate this framework briefly as: because of knowledge asymmetry (Austrian approach), personal differences (e.g., locus of control, Harper, 1998) and beliefs, individuals vary in their ability to access and extract resources, which are required in opportunity recognition and exploitation.

\section{FIGURE 3 \\ GENERAL FRAMEWORK FOR ENTREPRENEURSHIP}

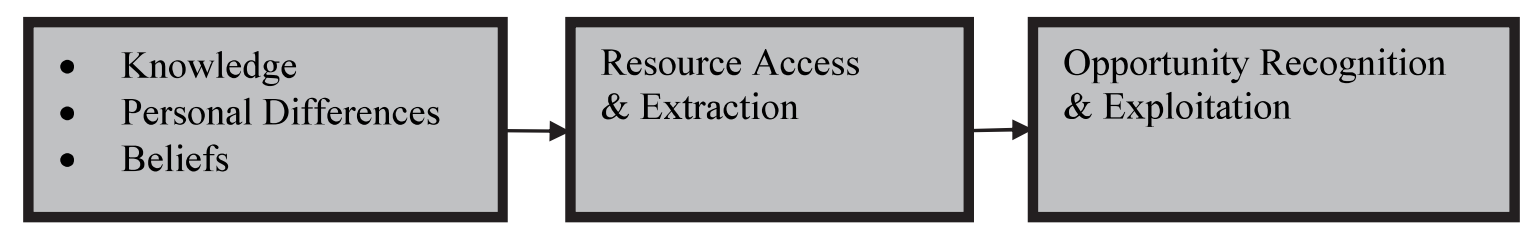

We extend this framework to the study of supply chain entrepreneurship as indicated in Figure 4. Supply chains differ considerably in the patterns of their supply chain partner networks. The patterns of a firm's supply chain partner network reveal firms' differences in accessing and extracting resources through relational competencies (learning, trust, and integration). Relational competencies are critical for developing supply chain capabilities for opportunity recognition and exploitation (agility, adaptability, and alignment).

By combining research from the three areas (social networks, entrepreneurship, and supply chain management), the proposed framework for supply chain entrepreneurship can be used to guide future research in many directions. From the network literature, in addition to network diversity and relationship strength introduced in this study, scholars can investigate how other network variables are related to relational competencies. For example, network embeddedness is the mechanism whereby an entrepreneur becomes part of the local structure and learns how to draw on and use the resources provided by available social capital (Anderson and Jack, 2002). Supply chain settings provide an opportunity for scholars to extend this idea from the traditional level of individuals to an inter-firm level by investigating the relationship between network embeddedness, access resource access and extraction. 


\section{FIGURE 4 \\ GENERAL FRAMEWORK FOR SUPPLY CHAIN ENTREPRENEURSHIP}

Supply chain differences
$\begin{aligned} & \text { Different Patterns of } \\ & \text { Supply Chain Partner } \\ & \text { Network }\end{aligned}$

In the entrepreneurship literature, organizational rejuvenation is an important corporate entrepreneurship form by which the organization seeks to sustain or improve its competitive standing by altering its internal processes, structures, and capabilities (e.g., Lejeune and Yakova, 2005; Peng et al., 2008; Shi and Gregory, 1998). A firm's supply chain management involves multiple hierarchical levels within a firm and horizontally spanning across firms. Supply chain entrepreneurship opens a new research domain that requires scholars to examine new processes, structures, and capabilities that enable a firm to rejuvenate its supply chains through opportunity identification and exploitation. Our research framework made such an attempt by exploring how the design of supply chain partner network, an entrepreneurial process of leveraging relationship strength and network diversity in enhancing learning, trust and integration, is related to supply chain agility, adaptability and alignment, which requires supply chain rejuvenation activities. For future research, scholars can look at how the design of supply chain partner network is related to specific supply chain rejuvenation practices, for example, lean and agile manufacturing, new product development, product customization, total quality management, risk management, and so on.

The literature has shown that a firm's entrepreneurial behaviors are contingent on its business environment (e.g., Miller and Friesen, 1982). Future research can examine the environmental effects on the design of supply chain partner network. For example, we can investigate the possible relationship between environmental dynamism and the relational dimensions of the partner network. Future studies also can examine other contingent variables, such as type of industries and firm age. For example, we can investigate whether industry type and firm age are associated with different patterns of supply chain partner networks.

\section{REFERENCES}

Anderson, A.R., \&Jack, S.L. (2002). The articulation of social capital in entrepreneurial networks: a glue or a lubricant? Entrepreneurship and Regional Development, 14(3), 193-210.

Berscheid, E., \& Walster, H. (1978). Interpersonal Attraction. Reading, MA: Addison-Wesley. Borgatti, S.P., \& Cross, R. (2003). A Relational View of Information Seeking and Learning in Social Networks. Management Science, 49(4), 432-445.

Borgatti, S.P., \& Li, X. (2009). Notes on social network analysis in supply chain context. Journal of Supply Chain Management, 45(2), 5-22.

Brass, D. (1995). A social network perspective on human resources management. Research in Personnel and Human Resources Management, 13, 39-79.

Braunscheidel, M.J., \& Suresch, N.C. (2009). The organizational antecedents of a firm's supply chain agility for risk mitigation and responses. Journal of Operations Management, 27, 119-140.

Burt, R. (1980). Models of network structure. Annual Review of Sociology, 6, 79-141.

Burt, R.S. (1983). Range. In R.S. Burt and M. J. Minor (Eds.), Applied Network Analysis: A Methodological Introduction. Beverly Hills, CA: Sage, 176-194. 
Burt, R. S. (1992). Structural Holes: The Social Structure of Competition. Boston: Harvard University Press.

Byrne, D. (1971). The Attraction Paradigm. New York: Academic Press.

Carey, S., Lawson, B., \& Krause, D. R. (2011). Social capital configuration, legal bonds and performance in buyer-supplier relationships. Journal of Operations Management, 29(4), 277-288.

Christopher, M. (1997). The agile supply chain: Competing in volatile markets. Industrial Marketing Management, 29(1), 37-44.

Coleman, J. S. (1988). Social capital in the creation of human capital. American Journal of Sociology, 94 , S95-S120.

Cousins, P.D., Handfield, R.B., Lawson, B., \& Petersen, K.J. (2006). Creating supply chain relational capital: The impact of formal and informal socialization processes. Journal of Operations Management, 24(6), 851-863.

Cousins, P.D. \& Menguc, B. (2006). The implications of socialization and integration in supply chain management. Journal of Operations Management, 24(5), 604-620.

Croxton, K., Garcia-Dastugue, S., Lambert, D., \& Rogers, D. (2001). The Supply Chain Management Processes. International Journal of Logistics Management, 12(2), 13-36.

Davis, E.W. \& Speckman, R.E. (2004). The extended Enterprise: Gaining competitive advantages through collaborative supply chains. London, U.K.: Financial Times Press.

Day, M., Fawcett, S.E., Fawcett, A.M., \& Magnan, G.M. (2013). Trust and relational embeddedness: Exploring a paradox of trust pattern development in key supplier relationships. Industrial Marketing Management, 42(2), 152-165.

Drucker, P.F. (1998). Managing in a Time of Great Change. New York: Truman Talley Books/Plume.

Dyer, J.H., \& Hatch, N.W. (2006). Relation-specific capabilities and barriers to knowledge transfers: Creating advantage through network relationships. Strategic Management Journal, 27(8), 701719.

Dyer, J.H. \& Singh, H. (1998). The relational view: Cooperative strategy and sources of interorganizational competitive advantage. Academy of Management Review, 23(4), 660-679.

Fabbe-Costes, N., \& Jahre, M. (2007). Supply chain integration improves performance: The Emperor's new suit? International Journal of Physical Distribution \& Logistics Management, 37(10), 835855.

Flynn, B.B., Huo, B., \& Zhao, X. (2010). The impact of supply chain integration on performance: A contingency and configuration approach. Journal of Operations Management, 28(1), 58- 71.

Frohlich, M.T., \& Westbrook, R. (2001). Arcs of integration: An international study of supply chain strategies. Journal of Operations Management, 19(2), 185-200.

Granovetter, M.S. (1973). The strength of weak ties. American Journal of Sociology, 6, 1360-1380.

Handfield, R.B., \& Bechtel, C. (2002). The role of trust and relationship structure in improving supply chain responsiveness. Industrial Marketing Management, 31, 367-382.

Harper, D.A. (1998). Institution condition for entrepreneurship. In Boettke, P.J., Kirzner, I.M. \& Rizzo, M.J. (Eds.). Advances in Austrian Economics, Volume 5, New York: JAI Press, 241-375.

Higgins, M.C., \& Kram, K.E. (2001). Reconceptualizing mentoring at work: A developmental network perspective. Academy of Management Review, 26(2), 264-288.

Hill, R.C., \& Levenhagen, M. (1995). Metaphors and mental models: sensemaking and sensegiving in innovative and entrepreneurial activities. Journal of Management, 21, 1057-1074.

Holweg, M., \& Pil, F.K. (2008).Theoretical Perspectives on the Coordination of Supply Chains. Journal of Operations Management, 26(3), 389-406.

Huber, G. (1991). Organizational learning: the contribution processes and the literature. Organization Science, 2(1), 88-115.

Hult, G. T. M., Ketchen, D. J., \& Slater, S. F. (2004). Information processing, knowledge development, and strategic supply chain performance. Academy of Management Journal, 47, 241-253.

Ibarra, H. (1993). Personal networks of women and minorities in management: A conceptual framework. The Academy of Management Review, 18(1), 56-87. 
Ivanov, D. (2010). An Adaptive Framework for Aligning (Re) planning Decisions on Supply Chain Strategy, Design, Tactics, and Operations. International Journal of Production Research, 48(13), 3999-4017.

Ketchen Jr., G. \& Hult, T.M. (2007). Bridging organization theory and SCM: the case of best-value supply chains. Journal of Operations Management, 25, (2), 573-580.

Kim, T., Oh, H., \& Swaminathan, A. (2006). Framing interorganizational network change: A network inertia perspective. Academy of Management, 31(3), 704-720.

Kirzner, I.M. (1973). Competition and Entrepreneurship. Chicago, IL: University of Chicago Press.

Kirzner, I.M. (1979). Perception, Opportunity and Profit: Studies in the Theory of Entrepreneurship. Chicago, IL: University of Chicago Press.

Krackhardt, D. (1990). Assessing the political landscape: structure, cognition, and power in organizations. Administrative Science Quarterly, 35, 342-369.

Krackhardt, D. (1992). The strength of strong ties: The importance of philos in organizations. In Nohria, N. and Eccles, R.G. (Eds.). Networks and Organizations: Structure, Form, and Action. Boston: Harvard Business School Press, 216-239.

Krackhardt, D. (1994). Constraints on the interactive organization as an ideal type. In C. Heckscher, A. Donnellon (Eds.). The Post-Bureaucratic Organization: New Perspective on Organizational Change. Thousand Oaks, CA: Sage Publications, 211-222.

Krackhardt, D., \& Stern, R.N. (1998). Informal networks and organizational crises: An experimental simulation. Social Psychology Quarterly, 51, 123-140.

Kang, S.C., Morris, S.S., \& Snell, S.A. (2007). Relational archetypes, organizational learning, and value creation: extending the human resource architecture. Academy of Management Review, 32(1), 236-256.

Koppl, R. (2002). Big Players and the Economic Theory of Expectations. Palgrave Macmillan, Basingstoke, Hampshire, UK.

Krause, D.R., Handfield, R.B., \& Tyler, B.B. (2007). The relationships between supplier development, commitment, social capital accumulation and performance improvement. Journal of Operations Management, 25(2), 528-545.

Lambert, D.M., \& Cooper, M.C. (2000). Issues in supply chain management. Industrial Marketing Management, 29(1), 65-83.

Lambert, D.M. (2008). Supply chain management. In Lambert, D.M. (Eds.), Supply Chain Management: Processes, Partnerships, Performance, $3^{\text {rd }}$ edition. Sarasota, FL: Supply Chain Management Institute, 1-23.

Lawson, B., Tyler, B.B., \& Cousins, P.D. (2008). Antecedents and consequences of social capital on buyer performance improvement. Journal of Operations Management, 26(3), 446-460.

Lee, H.L. (2004). The triple-a supply chain. Harvard Business Review, 83, 102-112.

Lejeune, M.A., \& Yahova, N. (2005). On characterizing the 4 C's in supply chain management. Journal of Operations Management, 23(1), 81-100.

Li, X., Goldsby, T.J., \& Holsapple, C.W. (2009). Supply chain agility: scale development. International Journal of Logistics Management, 20(2), 408-424.

Li, X., Chung, C., Goldsby, T., \& Holsapple, C.W. (2008). A unified model of supply chain agility: The work-design perspective. International Journal of Logistics Management, 19(3), 408-435.

Li, X. Wu, Q., \& Holsapple, C. (2015). Best Value Supply Chains and Firms' Performance Outcomes: Empirical Studies of Their Linkage. The International Journal of Operations \& Production Management, 35(12), 1688-1709.

Li, X., Wu, Q., Holsapple, C.W., \& Goldsby, T. (2017). An empirical examination of firm financial performance along dimensions of supply chain resilience. Management Research Review, 40(3), 254-269.

Liker, J.K., \& Choi, T.Y. (2004). Building deep supplier relationships. Harvard Business Review, 82(12), $104-113$.

Magee, D. (2009). Jeff Immelt and the New GE Way. McGraw-Hill, New York. 
Malhotra, A., Gosain, S., \& El Sawy, O. A. (2005). Absorptive capacity configurations in supply chains: gearing for partner-enabled market knowledge creation. MIS Quarterly, 29(1), 145-187.

Matusik, S.F., \& Hill, C.W. (1998).The utilization of contingent work, knowledge creation, and competitive advantage. Academy of Management Journal, 23, 680-697.

McEvily, B., \& Perrone, A., \& Zaheer, A. (2003). Trust as an organizing principle. Organization Science, 14(1), 91-103.

Meijboom, B., \& Obel, B. (2007). Tactical Coordination in a Multi-Location and Multi-Stage Operations Structure: A Model and a Pharmaceutical Company Case. Omega, 35(3), 258-73.

Miller, D., \& Friesen, P.H. (1982). Innovation in conservative and entrepreneurial firms: Two models of strategic momentum. Strategic Management Journal, 3(1), 1-25.

Modi, S.B., \& Mabert, V.A. (2007). Supplier development: Improving supplier performance through knowledge transfer. Journal of Operations Management, 25(1), 42-64.

Monczka, R.M., Petersen, K.J., Handfield, R.B., \& Ragatz, G.L. (1998). Success factors in strategic supplier alliances: the buying company perspective. Decision Sciences, 29(3), 553-577.

Paladino, B. (2000). What is Strategic-Operational Misalignment Costing Your Firm Each Year? Journal of Corporate Accounting \& Finance, 11(5), 47-56.

Peng, D.X., Schroeder, R.G., \& Shah, R. (2008). Linking routines to operations capabilities: A new perspective. Journal of Operations Management, 26(6), 730-748.

Petersen, K.J., Handfield, R.B., \& Ragatz, G.L. (2005). Supplier integration into new product development: coordinating product, process and supply chain design. Journal of Operations Management, 23(3-4), 371-388

Shi, Y.J., \& Gregory, M. (1998). International manufacturing networks-to develop global competitive capabilities. Journal of Operations Management, 16(2-3), 195-214.

Sinha, K.K., \&Van de Ven, A.H. (2005). Designing Work Within and Between Organizations. Organization Science, 16(4), 389-408.

Uzzi, B. (1997). Social structure and competition in interfirm networks: The paradox of embeddedness. Administrative Science Quarterly, 42(1), 35-67.

Uzzi, B., \& Lancaster, R. (2003). Relational embeddedness and learning: The case of bank loan managers and their clients. Management Science, 49(4), 383-399.

Zaheer, A., \& Zaheer, S. (1997). Catching the wave: Alertness, responsiveness, and market influence in global electronic networks. Management Science, 43(11), 1493-1509.

Zhang C, Viswanathan, S. \& Henke J.W. (2011). The boundary spanning capabilities of purchasing agents in buyer-supplier trust development. Journal of Operations Management, 29(4), 318-328. 